\title{
Hazardous child labor in Nepal: the case of brick kilns
}

\author{
Abstract \\ Hazardous child labor in Nepal is a serious concern, particularly in the brick kiln \\ industry. Although a range of interventions have been implemented in Nepal to \\ address hazardous child labor, there is a lack of research to both measure success and \\ shape further development in interventions that integrate sound child protection \\ practices to ensure the wellbeing of all children. This paper provides a review of the \\ literature outlining interventions for children working in brick kilns in Nepal, and \\ presents preliminary case study findings of one current intervention in the Kathmandu \\ Valley. The paper highlights the strength of applying foundational child protection \\ principles and advocates for the development and implementation of future programs \\ underpinned by broad civil society principles within a child rights and protection \\ framework.
}

\section{Introduction}

"All children have the right to be protected from economic exploitation and work" (United Nations Human Rights, 1989). Despite such well-intentioned aspirations, child labor remains a pervasive global problem. According to the International Labour Organization (ILO) (2013, 2015), one child in ten worldwide experiences life threatening work conditions. Hazardous child labor, defined as "work which by its nature or the circumstances in which it is carried out is likely to harm the health, safety, or morals of children” (ILO Convention 182), is among the worst forms of child labor, which the ILO has mandated to eliminate by 2016 (ILO, 2013). Over the past decade, the number of children working in hazardous forms of labor has halved, however it continues to be the largest category among the worst forms (ILO, 2013). These declines in prevalence reflect the aggregation of political commitment 
(ratifying international conventions and national legislation), investment in education and social protection, and promotion of alternative work opportunities (ILO, 2013). Yet much remains to be done if the elimination of worst forms of child labor is to be realized.

This paper presents a systematic review of the literature and case study focusing on hazardous child labor in the brick kilns of Nepal. There has been a range of suggested intervention frameworks to address hazardous labor in Nepal. Yet there is a dearth of research evidence linking current intervention models to principles of best practice in child protection. The application of key child protection principles is critical to the design and delivery of intervention strategies tailored to reduce harm for children working in brick kilns in Nepal. The first section of the paper provides a summary of current intervention approaches utilized within Nepal to address hazardous child labor. The second section uses a case study from an NGO in the Kathmandu Valley providing support for children working in brick kilns to highlight the application of best practice in child protection. These combined sources provide a basis to inform the development of future research and intervention designs within the Nepalese context to address hazardous child labor.

\section{Child labor: The Nepalese context}

The greatest absolute representation of child labor is in Asia and the Pacific, with an estimated 130,000 children working in the worst forms of child labor in Nepal alone (ILO, 2004, 2013). The situation of child labor in Nepal has received significant attention in recent decades (United States Department of Labor, 2014), especially under the spotlight of global export industries such as hand-knotted rugs. However, the extremely hazardous employment conditions observed in informal sectors, such as the brick industry, may be more detrimental to child wellbeing and remains largely 
unregulated (de Groot, 2010). With rapid growth in the industry responding to increasing demand for housing, child labor in the brick industry is of growing concern (ILO, 2014; World Education, 2013).

Nepal is an agro-based economy, and one of the poorest countries in the world (Nepal Ministry of Education, 2015). A third of children employed in worst forms in Nepal are illiterate, most have left formal education, come from large and landless families, and have migrated to urban centres for work (ILO, 2009). While the Nepalese Government and the Federation of Nepalese Brick Industries have attempted to regulate the industry, it remains largely unregulated (de Groot, 2010; MinErgy, 2012). Consequently, child labor in this industry often goes undocumented (de Groot, 2010). There are 429 registered brick kilns in Nepal, however the actual number is estimated in the vicinity of 700-750 (Gyawali, Sharma, \& Sharma, 2012; MinErgy, 2012). As such, estimates of the number of workers (adult and child) vary greatly, from 50,000 (FAO/RWEDP, 1993) to over 400,000 (General Federation of Nepalese Trade Unions, 2007). There is an estimated 30,000 children aged 5-17 years (Gyawali et al., 2012), although some estimate as many as 59,000 (CWIN factsheet 2007 in (de Groot, 2010)) working in the kilns. With over $80 \%$ of bricks produced in Nepalese brick fields used by households and petty contractors, brick price is the priority concern, rather than quality or ethical factors (MinErgy, 2012). Further, with the recent earthquake of April 2015, demand for bricks has risen with the demand for materials to rebuild the worst affected areas (Goda et al., 2015).

Labor in the brick kilns is seasonal, operating over winter months (World Education, 2013). Families are usually recruited through a contractor in their village, who provides a cash advance for the season, often forcing the family into debt bondage (de Groot, 2010; World Education, 2009a). Generally, work in the brick 
kilns is based on a piece rate payment (i.e. price per brick), and as such, help is enlisted from all family members, including children (de Groot, 2010). About half of the child workers are under 14 years of age, and come from lower castes (General Federation of Nepalese Trade Unions, 2007; World Education, 2013). About 60\% of workers are migrant (General Federation of Nepalese Trade Unions, 2007), and 39\% of children are in bonded labor (World Education, 2013). The primary reason documented for working in the kilns was employment opportunity; however, once employment was initiated, most perceived they were verbally or financially bonded for the season (General Federation of Nepalese Trade Unions, 2007). The work is labor intensive (molding stage and carrying bricks form the kiln (de Groot, 2010)), requiring high musculoskeletal effort, as well as exposure to hazards resulting in respiratory and dermatological disorders, and psychosocial compromise (ILO, 2014). A third of the children are working more than 12 hours daily (World Education, 2013). Children working in the brick fields were twice as likely to be sick compared to their peers (ILO, 2014), and regularly suffer from malnutrition (ILO, 2014). Over 60\% were found to have severe health consequences (General Federation of Nepalese Trade Unions, 2007). In addition to these direct workplace effects, $75 \%$ of workers live in shelters provided by the employer, in environments which are inadequate and lack basic sanitation (de Groot, 2010; General Federation of Nepalese Trade Unions, 2007; ILO, 2014). Child labor in the brick kilns is at odds with attending education, especially for seasonal migration (Majumder \& Mukherjee, 2011). Half of child laborers in brick kilns were reportedly attending school at their place of origin, with almost all of 348 surveyed (88\%) discontinuing at the workplace (General Federation of Nepalese Trade Unions, 2007). Only 24\% had a plan to reenroll after completion of their work (General Federation of Nepalese Trade Unions, 2007). 
In recent years, documentation describes the situation of child laborers in the brick kilns in Nepal articulating the employment context, group determinants and demographics, and the hazards and negative health outcomes associated with such work (de Groot, 2010; General Federation of Nepalese Trade Unions, 2007; ILO, 2014; Joshi \& Dahal, 2008; Joshi, Sharma, \& Shrestha, 2009; World Education, 2013). While the problem has been well defined, there is a lack of empirical data to support the most effective interventions to improve wellbeing among these child laborers in Nepal, in particular those interventions that focus on best practice. In this context this research provides a synthesis of current knowledge from the literature combined with an applied cased study of an NGO working with children in Nepalese brick kilns. It is hoped this will inform intervention and future research.

\section{Method}

\section{Search strategy}

A systematic search was conducted to guide the literature review using online databases, including Medline (1946-September 2015), PsycINFO (1840- September 2015), Scopus (1966- September 2015) and ERIC (via ProQuest1966- September 2015). Primary searches included keywords (“brick kiln*” or kiln* or "brick industry” or "bonded labo\#r” or "hazardous child labo\#r” or "hazardous labo\#r" or "child labo\#r” or “child work” or “child employment” or “exploitative labo\#r”) AND Nepal AND (intervention or “occupational health” or scholarship or "conditional cash transfer” or microfinance or outcome or psychosocial or psycholog* or injur* or musculoskeletal or respirat* or accident or wellbeing or education or school or health or illness or nutrition or stunt* or poverty or cognit*). Secondary searches broadened the geography to include ("South Asia” or "Central and South Asia” or "South and Central Asia” or “Asia”). Grey literature was searched using equivalent search terms, 
as well as manual searches conducted by reviewing reference lists and specific programs/interventions referenced in the texts.

\section{Inclusion/ exclusion criteria}

Documents were included for review if they described interventions meeting the following criteria: (1) Target participants were children aged $<18$ years laboring in the brick kilns in Nepal or South Asia; (2) Description of direct interventions for children working in brick kilns in Nepal or South Asia. Documents were excluded if they were not published in English.

Broad study criteria were employed for this review to gain a comprehensive understanding of interventions targeting hazardous labor for children working in brick fields in this geographical context, rather than only those with rigorous evaluation. While this approach may limit synthesis of findings, it is hoped this review will form a foundation for future intervention studies in this field. Although policy and legislation are valuable intervention approaches, this review focused specifically on grassroots interventions to support children working in brick kiln contexts.

\section{Data extraction and quality assessment}

A research assistant screened titles and abstracts of research publications and reports for eligibility and inclusion in the final review. Documents were retained if the content pertained to the target population, even if the application of an intervention was not evident from the title/abstract. Full-texts of documents were evaluated against inclusion criteria to confirm eligibility. Content analysis was undertaken for all eligible documents. This approach was considered the most suitable for making valid inferences about the selected material. Further, the employment of content analysis as a data collection and synthesis technique provided a robust framework for coding textual material through the process of extracting and tabulating data on the country, 
target population, intervention components, and reported outcomes of the intervention approach. The quality of the data was evaluated using the Cochrane Handbook 'GRADE' approach (Higgins \& Green, 2011). The GRADE approach was developed as a technique to support the facilitation of systematic reviews by defining the quality of a body of evidence. The GRADE approach delineates four levels of quality: 'high', 'moderate', 'low' and 'very low'. The highest quality rating is assigned to randomized trials and the lowest to sound observational studies. The following section presents the results of the systematic review.

\section{Results}

The initial search identified in total 326 documents. A final 21 documents were included that were awarded a high or moderate assessment using the GRADE approach.

(see Figure 1).

\section{[INSERT FIGURE 1 HERE]}

From these, 16 intervention programs were identified which target children working in brick kilns (or other forms of hazardous labor) in Nepal or South Asia. This included five interventions specific to children in brick kilns in Nepal, five interventions for children working in brick kilns in South Asia, and six interventions for other forms of hazardous child labor in Nepal. A synopsis of these interventions, including outcomes is provided below. 


\section{Brick Kiln Interventions in Nepal}

The following five interventions were identified for children working in brick kilns in Nepal: CONCERN ( $n=1500$ - 5 brick kilns) (The Advocacy Project n.d.); NonFormal Education Classes, NGO run ( $n=43$ - 5 brick kilns) (deGroot, 2010); Brighter Futures, World Education ( $n=1000)$ (WE, 2009); Naya Bato Naya Paila, World Education ( $n=1879)$ (WE, 2013); and Child Development Program, Care and Development Organization ( $n=7$ factories) (CDO, 2008). All five interventions gave significant focus to educational support (formal/non-formal/vocational/occupational safety/scholarships) with other identified supplementary intervention strategies including familial support, hygiene and health maintenance, food and nutritional support, micro-finance and children's clubs for three of the programs. The research outcomes for each intervention appear to lend support to the utility of these various models for intervening with children involved in hazardous labor in the brick kilns of Nepal, in terms of increased engagement in education. However, further attention needs to be given to broadening intervention targets beyond exposure to educational opportunity to account for the psychosocial and health needs of this vulnerable population. Table One provides a summary of outcomes associated with these intervention approaches.

\section{Brick Kiln Interventions in South East Asia}

The Bhonga Shala Experiment ( $n=30,000+$ from Thane District) (Jayachandran 2001; Vidhayak Sansad 2008, Patra 2007); Multiple Activity Centres implemented by Prayasam and UNICEF ( $n=2150$ - 26 brick kilns) (Mukherji 2010); the Mobile Schools intervention ( $n=2000$ - 65 brick kilns) (Majumder 2011); the Learning and Migration Program (LAMP) (Children of seasonal migrants, including brick kilns - 3 states) (Srivastava 2010); and the Brick kiln Education Centres ( $n=600$ - 50 kilns), 
Sarva Shiksha Abhiyan (SSA), Chengalpattu Area Brick Manufacturers Association and ILO (ILO 2012) represented five brick kiln interventions facilitated in South East Asia with varying measures of success.

Each intervention targeted Indian children working in brick kilns and gave emphasis to migrant tribal populations. All of the interventions maintained a focus on access to education through the utilisation of mobile schools and learning activity centres located within respective brick kiln communities. The Bhonga Shala Experiment and the Mobile Schools Project extended the focus of the intervention beyond school participation with each intervention including components that addressed factors including: transition support out of the sector; supplementary nutrition; parent liaison and regular health checks. Table Two provides further information about the outcomes of each intervention.

\section{Interventions Addressing other Forms of Hazardous Labor in Nepal}

Six interventions were identified for addressing other forms of hazardous labor for children in Nepal. The first, Strengthening Systems Approach, UNICEF (UNICEF 2011), provides a range of intervention strategies for children involved in child labor including rescue and emergency rehabilitation and reintegration (shelter, food, medical care), Psychosocial counseling, mediation with parents, legal support, education/vocational training and family support (IGS) ( $n=$ not specified). The second intervention, Out of School Program, UNICEF (UCW, 2003) provides educational support for child laborers who have not completed formal education ( $n=$ not specified). The third initiative, Sustainable Elimination of Child Bonded Labour in Nepal (ILO 2005, 2010), facilitated a range of supportive measures including prevention, withdrawal and rehabilitation approaches, out of school and bridging programs, income generation assistance and vocational training ( $n=14,000$ households). The 
Time Bound Programs, International Labour Organisation (ILO 2006, USDOL 2014, UCW 2003) is an intervention program that serves to strengthen legislation, promote child friendly labor, alleviate poverty, raise awareness about the worst forms of child labor, instigate withdrawal and provide access to education, healthcare and legal protection $(n=33,000)$. The fifth intervention, The School Incentives for Carpet Factory Workers (hand-made export) offers education scholarships for children involved in child labor as a means of increasing educational opportunity $(n=660)$. Finally, the Non-Formal Primary Education Program, Nepal Ministry of Education (Nepal Ministry of Education 2015) (Edmonds 2014) provides a three year condensed primary school education program for disadvantaged children including laborers. Table Three provides a summary of outcomes for these initiatives.

\section{Content}

All of the documents described education-related interventions. Most of the programs used a multi-pronged approach, with components broadly classified as: formal education (an organised approach guided by a formal curriculum that aligns with government standards leading to a specific level of attainment e.g. primary school completion) (6 interventions); financial educational support included scholarships, stipends, or in-kind support (4 interventions); non-formal education (NFE) (not adhering to a formalised curriculum nor leading to the attainment of a formal qualification e.g. life skills training, resilience development etc.) (12 interventions); day care/early learning (1 intervention); vocational education for working age children (3 interventions); seasonal hostels enabling children to stay in their home village during migration season (1 intervention); children’s clubs on work sites (2 interventions); nutritional support (3 interventions); health checks and hygiene awareness (5 interventions); family support (microfinance, livelihood support, 
financial literacy training (6 interventions); removal from work sites, including legal support (3 interventions); counselling and mediation (1 intervention); strengthening quality of government education (1 intervention); community-based advocacy (2 interventions); and prevention of at risk groups entering hazardous child labor (4 interventions)

The duration of intervention, dose (including frequency of access to services, number of components accessed) and timing of these intervention components were poorly described in all but one document (Edmonds \& Shrestha, 2014). The randomized control trial of school incentives for carpet factory workers in Nepal conducted by Edmonds (2014) clearly described the intervention involving an educational scholarship group, and scholarship plus stipend group.

Most of the documents reported intervention outcomes in absolute or raw data regarding program uptake. This included the number of enrolments in formal/nonformal/vocational education, average daily attendance, or the numbers receiving support (family, financial or seasonal accommodation). Only six of the 16 evaluations provided data to infer effectiveness of the intervention. These outcomes included percentage of children completing NFE who returned or continued with educational opportunities, percentage of successful completions, reductions in dropout rates, increases in class attendance, percentage change in grade failure or average percentage marks, or percentage reduction in labor participation. Four documents reported on reduction or removal from hazardous work. One document stated a reduction in occupational accidents and an increased awareness of risks, but did not indicate how this was measured. Five documents reported qualitative data (with or without quantitative data), such as child’s priorities, barriers to accessing interventions, attitude change and single case studies. 


\section{Quality}

All intervention evaluations were of very low scientific rigor, with the exception of Edmonds (2014) (Tables 1-3). This significantly limits our ability to interpret intervention effectiveness, make inferences concerning whether the designs are informed by sound child protection principles or synthesize results. Six documents presented general programmatic output data in the form of a NGO (or governmental) report without any formal study design or data analysis. Similarly, a further four studies reported non-experimental data, and one included only a single case. Of four very low quality evaluations that used quasi-experimental methods, one included informal observations and interviews (without qualitative study rigor); two reported pre-/post- data but included no statistical analysis; and one was a comparative survey between migrant and local child laborers, without any inferential analysis. The study by Edmonds (2014) was considered high- level evidence, being a well-conducted randomized trial. While random assignment to intervention and control groups was adequate, the overall sample was purposively sampled (with predefined 'at risk criteria'), and consequently findings may not be generalizable to other subgroups in the carpet industry, or to other industries using hazardous child labor (Edmonds \& Shrestha, 2014).

Overall, the quality of existing studies and reports on interventions on hazardous child labor in Nepal remains poor, with little reference to child protection principles or rigorous statistical analyses. Given this significant gap, and to illustrate the application and potential efficacy of applying child protection principles, we draw on case study material. This approach was considered an appropriate methodology to present the nuanced approaches of a specific intervention design currently being implemented in Nepal and to guide further empirical application and research. 


\section{A Nepalese NGO Responding to Hazardous Labor in Brick Kilns: A Case Study in Child Protection and Social Development}

The implementation of child protection practices within developing countries is gaining significant attention as a key determinant in poverty reduction (Holzmann, Sherburne-Benz \& Tesliuc, 2003). Child protection approaches require appropriate decision-making tools for systematized assessment to improve accuracy and rigor (Gillingham and Humphreys, 2010).

The case study methodology chosen for this research involved the recruitment of a nongovernment organization (NGO) currently supporting children working within six brick kiln communities in the Kathmandu Valley. At the time of recruitment for this study, the NGO was partnering with an International NonGovernment Organization (INGO) in the implementation of a broader child protection project focusing on exploitative and hazardous labor in Nepal. For two years, the first and second authors of this paper were engaged in a monitoring and evaluation project focusing on this broader intervention. The hazardous labor intervention component was facilitated over a two year period across the six brick kiln sites. The intervention design addresses current gaps in practices through the inclusion of: training specialist workers to expediently address local needs and provide effective and timely beneficiary support; tracking mechanisms to ensure ongoing support is offered to children and families; and professional supervision practices to increase workers’ accountability and the quality of child protection services implemented throughout the intervention.

Data was collected over two years and included quantitative descriptors delineating specific intervention targets at the post-intervention time point to determine the efficacy of the NGO's engagement across the intervention period. 
Qualitative data was also gathered and included in-depth interviews with the INGO and NGO personnel responsible for facilitating the intervention as well as a small sample of child beneficiaries $(n=252)$ who received support from the NGO. Quantitative data was analyzed descriptively and qualitative data was synthesized through thematic analysis. Data triangulation was achieved by identifying key features of the organization as well as specific intervention targets that promoted support for children recruited within the brick kiln communities. Given the focus of this paper is to use the case study to link key practice learning with themes associated with effective methods of intervention drawn from the systematic review, a synopsis of research findings is summarized, rather than in depth quantitative and qualitative results.

Post-intervention data emphasized significant gains made in specific child protection practices. The NGO's role in facilitating the intervention included the achievement of the following targets:

- to facilitate access for children to clean and safe drinking water

- to facilitate access to health facilities

- to promote child rights including the right to safety and education Specifically the activities include targeting migrant families in six brick kilns and the surrounding communities of Jaruwarashi and Badikhel within the Lalitpur District. The following key child protection principles are foundational to the intervention design and specific program activities:

- Child centered approaches including beneficiary participation and collaboration (goal formulation)

NGO staff offer specific activities for beneficiaries including regular weekly visits to brick kiln sites and emergency visits to address critical incidents. By 
focusing on building capacity, NGO personnel are supported by INGO personnel and encouraged towards effective skills utilization and critical action through a process of mutual problem conceptualization between the worker and beneficiary.

- A shift towards preventative approaches in contrast to curative measures A comprehensive case management system was developed including policy documents and systematic practice manuals to address critical incidents in the brick kilns. The case management system focuses on child protection utilizing a range of educational strategies including HEALTH, WASH and child protection to encourage a stronger emphasis on prevention to enhance the safety and wellbeing of all children.

\section{- Culturally sensitive practices}

NGO activities are closely monitored by key INGO personnel to promote greater awareness of the context where the workers are providing support and to develop sensitivity to the dynamics of power in relationships and the impact of this on service delivery to beneficiaries.

\section{- Practice frameworks informed by research}

Through the support of the INGO a range of training and development opportunities focusing on child protection and child and maternal health have been facilitated that encourage NGO personnel to engage within institutional opportunities and constraints and to include key stakeholders such as the Village Child Protection Committee (VCPC) and the Family Community Health Volunteers (FCHV) in the process.

- Professional supervision - The INGO personal facilitates monthly meetings with key NGO staff providing professional support and ongoing supervision 
and training to maintain sound practices in child protection and general service delivery.

These intervention approaches build accountability to both beneficiaries and donors. Outcomes to date show promising results indicating positive change in all intervention target areas.

\section{Discussion}

The issue of children working in hazardous conditions in the brick kilns of Nepal has gained recent attention in the literature. Numerous documents describe the adverse situation for these children and appeal for action. However, there is a distinct lack of empirical data evaluating effective interventions for this setting. Edmonds \& Shrestha (2014) highlight fundamental differences in optimal interventions for those in hazardous child labor compared to other forms of child labor. More specifically, the situation for the predominately migrant and financially bonded children in the brick kilns presents a unique set of challenges. As such, this review limited the scope to interventions for children laboring in brick kilns and other forms of hazardous labor, within a relatively homogenous cultural context. This paper reviewed 16 interventions for children in the brick kilns (and other forms of hazardous labor) in Nepal or South Asia, all of which focused on educational programs as a core intervention. Consistent with these findings, there is a general consensus in the broader literature that the most effective way to reduce child labor is through education (Paruzzolo, 2009). To strengthen the evidence base this paper presented a case study of an NGO's current intervention in six brick kilns in the Kathmandu Valley to illustrate the benefits of including a child protection framework to promote positive outcomes for child beneficiaries. However, there are challenges for NGOs working in this context and further empirical work is necessary to better identify the most effective intervention 
strategies and modalities and to assess systematically the efficacy of promising interventions. For example, there is a lack of specialist workers to assist children working in brick kilns in Nepal influencing the capacity of NGO workers to offer timely support to vulnerable children. The transient nature of families and the seasonal work within the brick kiln industry increases challenges for most locally based NGOs to track support for itinerant families. Also, the provision for professional supervision for NGO workers supporting brick kiln communities is often limited due to resource constraints and a lack of capacity and awareness of the benefits of ongoing worker supervision. Further, there is a strong agenda amongst NGOs working with brick kiln communities in Nepal to give emphasis to corporate social responsibility (CSR). An important consideration for improving the conditions for children working in brick kilns includes increasing the responsibility and accountability of brick kiln owners. Brick kiln entrepreneurs must give greater focus to the provision of a safe and sustainable work environment that includes access to education. To this end the Global Fairness Initiative and the Clean Brick Network of Nepal are working on brick kiln certification to improve conditions for children involved in this industry. Finally, the role of government is a key consideration in supporting children involved in hazardous labor in Nepal. One of the key challenges is the slow implementation and/or non-compliance to enforce regulations developed by government authorities to protect the rights of children working in brick kiln communities. The case study example, highlights the challenges to improving the capacity of NGOs in terms of fostering specialist expertise, monitoring of family movement within and between the brick kiln season and embedding rigorous supervision practices to improve service delivery including strategic intervention processes to improve child health and being. 
There is a relative wealth of literature about program effectiveness to increase educational attendance or attainment in the context of child labor, and somewhat less evidence of its reduction on labor participation rates. However, a stronger emphasis on the consideration of clear child protection principles to guide intervention design and implementation is imperative. This review offers insight into the breadth of programs functioning to support children in the brick kilns, and their emphasis on education. However, these documents provide little empirical evidence, focusing instead on program usage with limited attention to the immediate or longer-term impacts of the interventions for child or family wellbeing.

The case study illustrates an extension of current intervention designs, demonstrating how to infuse child protection principles into intervention design; specifying project targets that directly relate to key child wellbeing indicators such as provision of emergency support, increases in school participation, establishment of mobile health clinics and facilitation of hygiene awareness training. Such targets have benefited beneficiaries living and working within the six brick kiln communities under investigation. The case study further illustrates the importance of training specialist workers to provide comprehensive and timely support, integration of tracking mechanisms so that support is ongoing given the transient population recruited into the industry and professional supervision practice as a means to improve child protection service quality.

Child labor intervention approaches commonly are conceptualized as either protective or preventative (Paruzzolo, 2009). All of the reviewed programs primarily aimed to target children already involved in hazardous child labor (protective interventions), which can be considered either as protective eradication programs or alleviation programs (Paruzzolo, 2009). Three interventions involved direct removal 
of children (and associated reintegration services), but none of these were specific to the context of the brick kilns (hazardous labor). This ‘eradication’ approach is a priority for children engaged in worst forms of labor (Paruzzolo, 2009). Some researchers, however, suggest a trend away from this approach based on past experiences of rescued children reengaging in other potentially more exploitative work such as child sexual abuse (de Groot, 2007). Furthermore, these 'rescue' approaches fail to recognize the reasons children find themselves laboring in the brick kilns in the first place, with almost all citing poverty as the prevailing factor (General Federation of Nepalese Trade Unions, 2007). Removing children from this work, without addressing the resource constraints of families, may further exacerbate the cycle of poverty and disadvantage (Bhukuth \& Ballet, 2006). Protective interventions also encompass harm reduction approaches. Harm reduction approaches can include aims to harmonize education with employment (all 16 studies), and to improve the conditions in the work environment (de Groot, 2010; Paruzzolo, 2009), as implemented in five of the reviewed studies (CONCERN, Brighter Futures, Child Development Program, Bhonga Shala, Mobile Schools). Only four studies described a parallel preventative intervention arm, aimed at reducing entry into hazardous labor in the first place (Edmonds 2014, Time Bound Programs, SECBL, UNICEF Strengthening Systems Approach).

A number of different intervention components were utilized by the various programs, which we discuss in the context of the broader literature. The two broad models of child labor intervention can be understood as (1) those that affect the relative price of children's time; and (2) those that affect resource constraints and social risk management (Paruzzolo, 2009). For example, approaches used in the reviewed studies that are consistent with the former approach include formal, non- 
formal and vocational education; and enablers of these, such as financial educational support, seasonal accommodation, and strengthening the quality of government education. They also used components that aimed to reduce resource constraints and social risk, such as family support through microfinance and livelihood support.

A consistent feature of all of the brick kiln interventions was the establishment of site schools, either teaching the standard educational syllabus (as for the Bhonga Shala mobile schools) or more commonly, providing non-formal education (NFE). A number of these site schools provided programs with flexible schedules to cater for children's ongoing involvement in work in the brick kilns. While the NFE approach mitigates one important factor compromising child laborers' optimal development (access to education), in the absence of other harm reduction approaches, it may be inadequate for reducing physical and emotional consequences of hazardous labor.

The use of financial (or in-kind) incentives to support children to remain in education has been proven effective in several countries, both to increase enrolment and reduce child labor supply (Raju, 2006). Four of the reviewed interventions used financial educational supports, although only the study by Edmonds (2014) evaluated this rigorously, including its influence on hazardous forms of child labor. Other international studies on general forms of child labor highlight the efficacy of financial educational support, with scholarship programs found to reduce absenteeism by $30 \%$, increase attendance by 6-10 percentage points (Kremer, Miguel, \& Thornton, 2004), reduce dropout rates (Cameron, 2002), and reduce child labor (Henschel, 2002; Schultz, 2004). It is important to note, however, that there are significant differences between the carpet industry and brick kilns. Carpet weaving work is not seasonal and children often live in their own homes and have access to local schools. In contrast, the seasonal nature of work in the brick kilns creates more frequent disruption for 
families and presents a unique challenge for intervention projects to provide consistent services as children migrate for work.

Family poverty is recognized as a major contributor towards child labor (World Education, 2009b), cited as the major reason for work in the brick kilns (General Federation of Nepalese Trade Unions, 2007). As such, it would seem plausible that these approaches aiming to affect the relative price of children's time (through educational programs) would be delivered along with approaches to reduce financial constraints and social risks faced by families. This pairing of approaches was employed in six of the interventions reviewed, namely provision of microfinance, financial literacy and livelihood support. None of the interventions reviewed specifically evaluated this component of the intervention, neither its effectiveness in improving family livelihoods, nor its effect on child labor participation. Given poverty is a primary reason why children work in the brick industry, it is reasonable to hypothesize that finance focused forms of support, seemingly should reduce a child's need to work. However, a number of studies have shown evidence to the contrary (Hazarika \& Sarangi, 2005; Islam \& Choe, 2013). These studies attribute the adverse effects of microcredit on child labor participation to the increased opportunity and need for labor within the new family enterprises. There are, however, examples of effective microcredit programs that are directed at child laborers to give them safer and more flexible alternatives to exploitative work (Edmonds, 2006).

The outcomes evaluated in the reviewed studies tended to report crude output data, rather than applying rigorous statistical analysis. Furthermore, most studies only looked broadly at participation in educational programs or child labor. The SAFE model, grounded in a rights based approach, considers four key areas as critical when evaluating outcomes for vulnerable youth: their Safety, Access to health care and 
basic physiological needs, Family and connection to others, Education and economic security (Betancourt et al, 2010). No single measure exists as a gold standard for the evaluation of such outcomes. However, the ILO has published a document that outlines a number of useful measures, and their application for the assessment of psychosocial hazards and impacts of child labor (ILO, 2011). While the case study presented in this paper also focuses on descriptive outcomes, it does conform to rigorous child protection frameworks including the SAFE model and paves the way for future work focused on hazardous labor and cogent child protection practice. However, there remains a critical need for a comprehensive approach to outcome evaluation that captures a range of indicators of child and family wellbeing based on strong empirical designs (Paruzzolo, 2009).

The presented case study offers one model for addressing a range of needs for children working in brick kilns. The intervention targets three critical components to improve the quality of life of children engaged in this type of hazardous labor: access to clean and safe drinking water; access to health facilities; and the promotion of child rights including the rights to safety and education. Further, the specialist training included in the case study intervention design, combined with methods for tracking transient beneficiaries to ensure ongoing support and the inclusion of rigorous professional supervision processes extends upon current practices in hazardous labor intervention programs. These components should be foundational to all brick kiln interventions to ensure that children are provided with comprehensive support necessary to their fundamental needs.

The case study emphasizes a holistic approach to promote fair access to education and harm reduction for the child's physical and emotional wellbeing. Interventions based on the SAFE model aim to: ensure all children are attending local 
schools within close proximity to each brick kiln; monitor the occupational safety of all children through regular surveillance from the Family Community Health Volunteers (FCHV) and the NGO personnel; provide supplementary nutrition and medication to promote health; and facilitate regular health checks and hygiene maintenance through the use of strategies such as mobile health clinics. The case study highlights the importance of case management practices that increase worker accountability for measuring outcomes including the ongoing monitoring and evaluation of beneficiary wellbeing.

Finally, the case study intervention model highlights the significance of embedding clearly delineated child protection principles to guide and sustain practices that serve to promote child rights and improve children's wellbeing. Such principles include: effective skills utilization; critical action through a process of mutual problem conceptualization between worker and beneficiary; identification of opportunities for change and preventative action; promotion of beneficiary wellbeing; awareness of context in the provision of support; the impacts of power in relationships; challenging patterns of disadvantage; and recognizing and responding to institutional opportunities and constraints (Tilbury et al., 2007).

\section{Limitations and Recommendations}

A pressing priority to eliminate the worst forms of child labor is the development of rigorous empirical evidence to support effective interventions. This literature review revealed a significant gap in this evidence base with only one study out of the 16 reviewed considered strong methodologically, with all remaining studies having very low level empirical evidence. Academic research in this field is greatly needed, particularly well-designed studies such as randomized controlled trials and case control studies. Government and nongovernment agencies also have an obligation to 
conduct rigorous program evaluations and to disseminate findings within the scientific community. Strategic selection of programs for evaluation, rather than donor driven priorities, will ensure research is targeted for greatest impact (Paruzzolo, 2009).

Studies need to evaluate both direct and indirect intervention outcomes to avoid unforeseen consequences. In particular, educational programs in this setting should focus not only on the educational outcomes (enrolments, attendance, grades), but evaluate changes to child labor participation. Further, evaluation should employ industry recognized measures of child and family wellbeing, in addition to program utilization data. A challenge in providing interventions and adequate long-term evaluation of outcomes for children in the brick kilns is their mobility. Research in this field should consider follow up in origin communities to gain an understanding of the ongoing benefits and challenges of the intervention. Finally, there is a need for research conducted by research personnel who are not directly involved in the implementation of interventions. Many programs have underdeveloped monitoring and evaluation integrity systems.

Drawing on this review of the broader literature, and the case study, the following promising intervention components for improving outcomes for child laborers in brick kilns should be considered when planning future interventions:

- Financial educational supports, particularly ongoing stipend payments conditional on school attendance show promising results. Limitations to financial sustainability are important to consider if such interventions are to be scaled up. This requires cost benefit analysis.

- On-site educational programs have high documented participation rates and are feasible for NGOs to deliver. More rigorous evaluation of the benefits of 
such programs is critical.

- Harm reduction interventions for children who continue to work is a significant knowledge gap. This is of great importance, as most interventions delivered to date are protective alleviation strategies (providing education in the work environment) rather than protective elimination or preventative strategies.

- Studies are needed to evaluate the role of family financial support specific to the brick kiln industry. Many migrant families to the brick kilns are agrarian who take cash advances for brick kiln employment due to financial limitations. Providing microfinance or livelihood support may therefore prevent families from migrating for seasonal work, thus mitigating financial bondage and child labor.

- Intervention designs should take account of sound principles of child protection to facilitate holistic approaches that address all the needs of the child to promote optimal health and wellbeing. As highlighted in the case study, a strong emphasis on ongoing case management including specialist training, tracking of transient workers and professional supervision is mandatory to the effectiveness of intervention programs for hazardous child labor.

\section{Conclusion}

Evidence from the literature and case study show the perils of hazardous child labor in Nepal. This highlights there are significant gaps in empirically tested intervention on child labor in brick kilns. While country specific contexts are critical for programming and research design, numerous points arising from this research are relevant for intervening in child labor globally. Migration and bonded labor illustrate 
the complex underlying socio-economic foundations that require a sociopolitical response. These structural issues must be taken into account when designing intervention strategies that directly target children and families. Caution is needed to ensure that programming does not serve to soften the impact of child labor in the absence of structural reform and advocacy. Global and local corporate responsibility cannot be excluded from the strategy. The importance of evidence-based programming is critical to this balance. 


\section{References}

Betancourt, T. S., Fawzi, M. K. S., Bruderlein, C., Desmond, C., \& Kim, J. Y. (2010). Children affected by HIV/ AIDS: SAFE, a model for promoting their security, health, and development. Psychology, Health and Medicine, 15(3), 243-265.

Bhukuth, A., \& Ballet, B. (2006). Is child labour a substitute for adult labour? International Journal of Social Economics, 33(8), 594-600.

Cameron, L. A. (2002). Did social safety net scholarships reduce drop-out rates during the Indonesian Economic Crisis?: World Bank Policy Research Working Paper No. 2800.

Care and Development Organization. (2008). Brick kilns and children’s life. Retrieved from http://www.caredevelopment.org

de Groot, A. (2007). Deprived children and education: Nepal. Retrieved from http://www.crin.org/docs/Nepal_Education.pdf

de Groot, A. (2010). Child labour in Kathmandu, Nepal. Leiden: IREWOC.

Duflo, E., Dupas, P., Kremer, M., \& Sinei, S. (2006). Education and HIV/AIDS prevention: Evidence from a randomized evaluation in Western Kenya. Washington, D.C.: The World Bank.

Edmonds, E. V. (2006). Alternative income generation and entry into worst forms of child labor: Theory and evidence from ragpickers, porters, and child domestics in Nepal. A report prepared for the International Child Labor Program of the Bureau of International Labor Affaires, US Department of Labor. Department of Economics, Dartmouth College and the National Bureau of Economic Research. 
Edmonds, E. V. (2007). Child labor: Working Paper 12926. Cambridge: National Bureau of Economic Research.

Edmonds, E. V., \& Shrestha, M. (2014). You get what you pay for: Schooling incentives and child labor. Journal of Development Economics, Preprint forthcoming 2015.

Evans, D., Kremer, M., \& Ngatia, M. (2009). The impact of distributing school uniforms on children's education in Kenya. Working Paper. Washington, D.C.: The World Bank.

FAO/RWEDP. (1993). Staus and development issues of the brick industry in Asia: Field Document No. 35. Bangkok: FAO Regional Wood Energy Development Programme in Asia.

General Federation of Nepalese Trade Unions. (2007). Nepal: Labour under the chimney. A study on the brick kilns of Nepal. Kathmandu, Nepal: GEFONT.

Gillingham, P., \& Humphreys, C. (2010). Child protection practitioners and decisionmaking tools: Observations and reflections from the front line. British Journal of Social Work, 40(8), 2598-2616.

Goda, K., Kiyota, T., Pokhrel, R.M., Chiaro, G., Katagiri, T., Sharma, K. \& Wilkinson, S. (2015). The 2015 Gorkha Nepal earthquake: insights from earthquake damage survey. Frontiers in Built Environment, 1(8), 1 - 15.

Gyawali, K., Sharma, S., \& Sharma, R. (2012). A rapid assessment of children in the brick industry. Kathmandu, Nepal: World Education and Plan Nepal. 
Hazarika, G., \& Sarangi, S. (2005). Household access to microcredit and child work in rural Malawi: IZA Discussion Paper No. 1567. Bonn, Germany: Institute for the Study of Labor (IZA).

Henschel, B. (2002). Child labour related programmes: a review of Impact evaluations: Understanding Child Work Working Paper. Retrieved from http://documents.worldbank.org/curated/en/805201468313504831/pdf/438680 WP0Box321tevaluation01PUBLIC1.pdf

Higgins, J. P. T., \& Green, S. (Eds.). (2011). Cochrane handbook for systematic reviews of interventions Version 5.1.0 [updated March 2011]. The Cochrane Collaboration.

Holzmann, R., Sherburne-Benz, L., \& Tesliuc, E. (2003). Social risk management: the World Bank's approach to social protection in a globalizing world. Washington, D.C.: Social Protection Department, The World Bank.

ILO. (2004). Child labour and responses in South Asia: Overview Note - Nepal. Retrieved from http://www.ilo.org/legacy/english/regions/asro/newdelhi/ipec/responses/index. htm

ILO. (2005). Sustainable Elimination of Bonded Labour in Nepal (Phase I): ILO Evaluation Summaries. Geneva, Switzerland: International Labour Organization.

ILO. (2006). Supporting the Time-Bound Programme on the elimination of the worst forms of child labour in Nepal: Evaluation Summaries. Geneva, Switzerland: International Labour Organization. 
ILO. (2009). Child labour and responses: Overview note - Nepal.

ILO. (2010). Sustainable Elimination of Child Bonded Labour in Nepal: Phase II: ILO Evaluation Summaries. Geneva, Switzerland: International Labour Organization.

ILO. (2011). Assessing psychosocial hazards and impact of child labour. Geneva, Switzerland: International Labour Organization.

ILO. (2012). Practices with good potential- Towards the elimination of hazardous child labour. Geneva, Switzerland: International Labour Organization.

ILO. (2013). Marking progress against child labour - Global estimates and trends 2000-2012. Geneva, Switzerland: International Labour Organization.

ILO. (2014). Occupational health and safety assessment of child workers in the brick industry, Nepal. Geneva, Switzerland: International Labour Organization.

ILO. (2015). What is child labour. Retrieved from http://www.ilo.org/ipec/facts/langeng/index.htm

Islam, A., \& Choe, C. (2013). Child labour and schooling responses to access to microcredit in rural Bangladesh. Economic Inquiry, 51(1), 46-61.

Jayachandran, U. (2001). Taking schools to children: 'Bhonga Shalas'. Economic and Political Weekly, 36(35), 3347-3350.

Joshi, S. K., \& Dahal, P. (2008). Occupational health in small scale and household industries in Nepal: A situation analysis. Kathmandu University Medical Journal, 6(2), 152-160. 
Joshi, S. K., Sharma, S. C., \& Shrestha, S. (2009). Child labour in Nepal and associated hazards: a descriptive study. Asian Pacific Newsletter on Occupational Health and Safety, 16, 66-69.

Kremer, M., Miguel, E., \& Thornton, R. (2004). Incentives to learn: NBER Working Paper No.10971.

Kremer, M., Moulin, S., \& Namunyu, R. (2003). Decentralization: A cautionary tale. Poverty Action Lab Paper, 10. The Abdul Latif Jameel Poverty Action Lab.

Majumder, R., \& Mukherjee, D. (2011). Paternal migration, child labour and education: a study in brickfield areas of West Bengal. Munich, Germany: Munich Personal RePEc Archive.

MinErgy. (2012). A roadmap for efficient brick production in Nepal. Renewable Energy \& Energy Efficiency Promotion in International Cooperation. Retrieved from http://www.repic.ch/files/6113/7544/1756/SB_AGHH_Minergy_Road_Map.p df

Mukherji, R. (2008). A school for brick kiln children. Retrieved from http://www.teacherplus.org/2008/november-december/a-school-for-brick-kilnchildren

Nepal Ministry of Education. (2015). Education for Al 2015 National Review. Kathmandu, Nepal: UNESCO.

Pant, P. R., Budhathoki, B., Ellis, M., Manandhar, D., Deave, T., \& Mytton, J. (2015). The feasibility of community mobilisation for child injury prevention in rural 
Nepal: a programme for female community health volunteers. BMC Public Health, 15, 430-442.

Paruzzolo, S. (2009). The impact of programs relating to child labor prevention and children's protection: a review of impact evaluations up to 2007. Rome, Italy: Understanding Children's Work Project.

Patra, R. (2007). Out-of-school children: the 'abhiyan' to bring them to school. CYBERART Information Pty Ltd.

Raju, D. (2006). The effect of conditional cash transfers on child work: A critical review and analysis of the evidence. Washington, D.C.: The World Bank.

Schultz, T. W. (2004). School subsidies for the poor: Evaluating the Mexican Progresa poverty program. Journal of Development Economics, 74, 199-250.

Srivastava, R., \& Dasgupta, R. (2010). Small steps lead the way: The Learning And Migration Programme (LAMP) of the AIF: A review. New Delhi, India: American India Foundation.

The Advocacy Project. (n.d.). Children and Environment Nepal (CONCERN) and child labor in the brick kilns. Retrieved from http://www.advocacynet.org/partners/concern

Tilbury, C. (2007). Good practice in child protection. Frenchs Forest, Australia: Pearson Education.

Understanding Children's Work: An Inter-Agency Research Cooperation Project. (2003). Understanding children's work in Nepal: Report on child labour. Rome, Italy: Understanding Children's Work Project. 
UNICEF. (2011). Child labour and UNICEF in action: children at the centre. New York: UNICEF.

United Nations Human Rights. (1989). Convention on the Rights of the Child.

Retrieved from http://www.ohchr.org/en/professionalinterest/pages/crc.aspx

United States Department of Labor. (2014). Nepal: 2014 findings on the worst forms of child labor. Retrieved from http://www.dol.gov/ilab/reports/childlabor/nepal.htm

Vidhayak Sansad. (2008). Educational activities - Bhonga Shala (schools for migrant children). Retrieved from http://www.vidhayaksansad.org/edu_activities.htm.

World Education. (2009a). Brighter Futures Program: Executive Summary.

World Education. (2009b). Improved family livelihoods to address child labor: Child Labor Strategies Report. Retrieved from http://www.worlded.org/WEIInternet/inc/common/_download_pub.cfm?id=10 686\&lid $=3$

World Education. (2013). Naya Bato Naya Paila: Combating exploitative child labor through education in Nepal 2009-2013. Kathmandu, Nepal: World Education. 
Table 1. Interventions for reducing the impact of hazardous labor for children working in brick kilns in Nepal $(n=5)$

\begin{tabular}{|c|c|c|c|c|c|}
\hline $\begin{array}{l}\text { Program/ } \\
\text { Organisation }\end{array}$ & Country & $\begin{array}{l}\text { Target } \\
\text { Population } \\
\text { and Sample } \\
\text { Size }\end{array}$ & Intervention & Outcomes & $\begin{array}{l}\text { Study } \\
\text { Quality }\end{array}$ \\
\hline $\begin{array}{l}\text { CONCERN } \\
\text { (The Advocacy } \\
\text { Project n.d.) }\end{array}$ & Nepal & $\begin{array}{l}\text { Children in } \\
\text { brick kilns } \\
\mathrm{N}=1500 \text { (in } 5 \\
\text { brick kilns) } \\
\text { [estimation } \\
\text { only] }\end{array}$ & $\begin{array}{l}\text { Non-formal } \\
\text { Education } \\
\text { (NFE) } \\
\text { Cooperation } \\
\text { with } \\
\text { government } \\
\text { schools } \\
\text { Day care } \\
\text { (including } \\
\text { meal) } \\
\text { Children's } \\
\text { clubs } \\
\text { (including } \\
\text { rights) } \\
\text { Education } \\
\text { support in } \\
\text { native village } \\
\text { post-season } \\
\text { (including } \\
\text { support for } \\
\text { uniforms, } \\
\text { stationery, } \\
\text { fees) }\end{array}$ & $\begin{array}{l}99 \text { day care } \\
\text { enrolments } \\
142 \text { non-formal } \\
\text { enrolments } \\
682 \text { enrolment } \\
\text { support } \\
900 \text { children's club } \\
\text { enrolment }\end{array}$ & $\begin{array}{l}\text { Very low: } \\
\text { NGO report }\end{array}$ \\
\hline $\begin{array}{l}\text { Non-Formal } \\
\text { Education } \\
\text { Classes, NGO } \\
\text { run (deGroot } \\
2010 \text { ) }\end{array}$ & Nepal & $\begin{array}{l}\text { Children in } \\
\text { brick kilns } \\
\mathrm{N}=43 \text { (in } 5 \\
\text { brick kilns) }\end{array}$ & $\begin{array}{l}\text { Non-formal } \\
\text { Education } \\
\text { (NFE) }\end{array}$ & $\begin{array}{l}10 \text { attendees (av) } \\
\text { per day } \\
\text { Qualitative: } \\
\text {-Work/ family } \\
\text { responsibilities } \\
\text { prioritised over } \\
\text { school } \\
\text {-Distance and } \\
\text { cost were barriers } \\
\text {-Single case } \\
\text { series }\end{array}$ & $\begin{array}{l}\text { Very low: } \\
\text { Primary data - } \\
\text { observations, } \\
\text { interviews, } \\
\text { single case } \\
\text { study }\end{array}$ \\
\hline $\begin{array}{l}\text { Brighter } \\
\text { Futures, World } \\
\text { Education (WE } \\
\text { 2009) }\end{array}$ & Nepal & $\begin{array}{l}\text { Children in } \\
\text { brick kilns } \\
\mathrm{N}=1000\end{array}$ & $\begin{array}{l}\text { Non-formal } \\
\text { Education } \\
\text { (NFE) } \\
\text { Scholarships } \\
\text { for formal } \\
\text { education (in- } \\
\text { kind) } \\
\text { Improved } \\
\text { quality of } \\
\text { education } \\
\text { (PTA) } \\
\text { Occupational } \\
\text { safety } \\
\text { modules } \\
\text { Vocational }\end{array}$ & $\begin{array}{l}912 \text { attended NFE. } \\
20 \% \text { of NFE } \\
\text { graduates } \\
\text { enrolled in formal } \\
\text { school. } \\
\text { 48\% of NFE } \\
\text { graduates joined } \\
\text { vocational } \\
\text { training. } \\
\text { 293/1578 received } \\
\text { scholarships. } \\
\text { Fewer accidents. } \\
\text { Greater awareness } \\
\text { of occupational } \\
\text { risks }\end{array}$ & $\begin{array}{l}\text { Very low: } \\
\text { Secondary } \\
\text { data only } \\
\text { (reporting on } \\
\text { pre-/post- } \\
\text { survey and } \\
\text { single case } \\
\text { study) }\end{array}$ \\
\hline
\end{tabular}




\begin{tabular}{|c|c|c|c|c|c|}
\hline & & & $\begin{array}{c}\text { education } \\
\text { Microfinance }\end{array}$ & Single case study & \\
\hline $\begin{array}{l}\text { Naya Bato } \\
\text { Naya Paila, } \\
\text { World } \\
\text { Education (WE } \\
\text { 2013) }\end{array}$ & Nepal & $\begin{array}{l}<14 \text { years, } \\
\text { female, dalit/ } \\
\text { janjati, no or } \\
\text { minimal } \\
\text { schooling } \\
\text { (prioritised): } \\
\text { brick kilns } \\
\text { were sub- } \\
\text { group } \\
\mathrm{N}=1879\end{array}$ & $\begin{array}{l}\text { Educational } \\
\text { support } \\
\text { Family support } \\
\text { (financial } \\
\text { literacy, } \\
\text { microfinance } \\
\text { access, } \\
\text { livelihood } \\
\text { support) } \\
\text { Non-formal } \\
\text { Education } \\
\text { Scholarship to } \\
\text { attend school } \\
\text { (uniforms, } \\
\text { stationery, } \\
\text { fees) } \\
\text { Coaching } \\
\text { classes }\end{array}$ & $\begin{array}{l}1180 \text { received NFE } \\
580 \text { were supported } \\
\text { to formal } \\
\text { schooling } \\
103 \text { received } \\
\text { vocational } \\
\text { training } \\
\text { Overall (including } \\
\text { other sectors): } \\
\text {-91.5\% of } \\
\text { education (formal } \\
\text { and informal) } \\
\text { participants } \\
\text { successfully } \\
\text { completed. } \\
\text {-74.2\% of NFE } \\
\text { participants } \\
\text { transitioned to } \\
\text { FE. } \\
\text {-Average days of } \\
\text { class attended } \\
\text { increased by } 40 \\
\text { days post } \\
\text { coaching (70\% } \\
\text { attendance). } \\
\text { - Average \% } \\
\text { marks in school } \\
\text { exams improved } \\
\text { by } 10.6 \% \text { post } \\
\text { coaching. } \\
\text {-4063 families } \\
\text { received support. }\end{array}$ & $\begin{array}{l}\text { Very low: } \\
\text { Pre-/post- } \\
\text { data. No } \\
\text { statistical } \\
\text { analysis }\end{array}$ \\
\hline $\begin{array}{l}\text { Child } \\
\text { Development } \\
\text { Program, Care } \\
\text { and } \\
\text { Development } \\
\text { Organization } \\
\text { (CDO 2008) }\end{array}$ & Nepal & $\begin{array}{l}\text { Children in } \\
\text { brick kilns. } \\
\mathrm{N}=7 \text { factories }\end{array}$ & $\begin{array}{l}\text { Nutritional food } \\
\text { Hygiene } \\
\text { maintenance } \\
\text { Non-formal } \\
\text { education } \\
\text { Health checks }\end{array}$ & $\begin{array}{l}120 \text { benefited } \\
30 \text { children } \\
\text { sponsored in } \\
\text { formal education } \\
\text { Includes case } \\
\text { studies }\end{array}$ & $\begin{array}{l}\text { Very low: } \\
\text { NGO report }\end{array}$ \\
\hline
\end{tabular}


Table 2. Interventions for reducing the impact of hazardous labor for children in brick kilns in South Asia (n=5)

\begin{tabular}{|c|c|c|c|c|c|}
\hline Program/ Organisation & Country & $\begin{array}{l}\text { Target Population and } \\
\text { Sample Size }\end{array}$ & Intervention & Outcomes & Study Quality \\
\hline $\begin{array}{l}\text { Bhonga Shala Experiment } \\
\text { (Jayachandran 2001; } \\
\text { Vidhayak Sansad 2008, } \\
\text { Patra 2007) }\end{array}$ & India & $\begin{array}{l}\text { Children in brick kilns } \\
\text { (particularly migrant } \\
\text { tribal). } \\
\mathrm{N}=30,000+\text { from Thane } \\
\text { District }\end{array}$ & $\begin{array}{l}\text { Mobile schools on site } \\
\text { (mainstream primary } \\
\text { syllabus) during brick season. } \\
\text { Examinations and certificates } \\
\text { provided to enable transition } \\
\text { to native schools off-season. } \\
\text { Transition support. } \\
\text { Supplementary nutrition. } \\
\text { Health checks. }\end{array}$ & $\begin{array}{l}\text { 72-77\% readmission rates. } \\
90 \% \text { pass rates in state exams. }\end{array}$ & $\begin{array}{l}\text { Very low: } \\
\text { Outcome data from } \\
\text { NGO reports }\end{array}$ \\
\hline $\begin{array}{l}\text { Multiple Activity Centres, } \\
\text { Prayasam and UNICEF } \\
\text { (Mukherji 2010) }\end{array}$ & India & $\begin{array}{l}\text { Children in brick kilns } \\
\mathrm{N}=2150 \text { ( } 26 \text { brick kilns) }\end{array}$ & Multiple Activity Centres (NFE) & Qualitative case studies & $\begin{array}{l}\text { Very low: } \\
\text { Single case studies }\end{array}$ \\
\hline $\begin{array}{l}\text { Mobile schools } \\
\text { (Majumder 2011) }\end{array}$ & India & $\begin{array}{l}\text { Children in brick kilns } \\
\mathrm{N}=2000 \text { (65 brick kilns) }\end{array}$ & $\begin{array}{l}\text { Child education (NFE) } \\
\text { Hygiene } \\
\text { Livelihoods } \\
\text { Health check-ups } \\
\text { Parent liaison }\end{array}$ & $\begin{array}{l}\text { 20-45\% of local children accessing } \\
\text { NFE centres vs no migrant children. } \\
\text { 5-20\% of local children are out of } \\
\text { school vs. } 100 \% \text { of migrant } \\
\text { children. }\end{array}$ & $\begin{array}{l}\text { Very low: } \\
\text { Comparative survey, } \\
\text { no statistics }\end{array}$ \\
\hline $\begin{array}{l}\text { Learning and Migration } \\
\text { Program (LAMP) } \\
\text { (Srivastava 2010) }\end{array}$ & India & $\begin{array}{l}\text { Children of seasonal } \\
\text { migrants, including brick } \\
\text { kilns (3 states) }\end{array}$ & $\begin{array}{l}\text { Site schools } \\
\text { Seasonal hostels } \\
\text { Bridge courses } \\
\text { Community-based advocacy } \\
\text { Village councils to improve } \\
\text { school management and } \\
\text { planning }\end{array}$ & $\begin{array}{l}15844 \text { children enrolled in site } \\
\text { schools. } \\
6081 \text { children in seasonal hostels. } \\
3208 \text { children in bridge courses. } \\
48 \text { admitted to high school. } \\
7 \% \text { schooling coverage in sugarcane } \\
\text { areas, but no estimates for brick } \\
\text { fields. }\end{array}$ & $\begin{array}{l}\text { Very low: } \\
\text { Review report - NGO } \\
\text { data for accountability }\end{array}$ \\
\hline $\begin{array}{l}\text { Brick kiln education } \\
\text { centres, Sarva Shiksha } \\
\text { Abhiyan (SSA), } \\
\text { Chengalpattu Area Brick } \\
\text { Manufacturers } \\
\text { Association and ILO (ILO } \\
\text { 2012) }\end{array}$ & India & $\begin{array}{l}\text { Children in brick kilns } \\
\mathrm{N}=600 \text { (50 kilns) }\end{array}$ & $\begin{array}{l}\text { Facilitation of formal enrolment } \\
\text { Non-formal education } \\
\text { Transfer certificates }\end{array}$ & $\begin{array}{l}174 \text { enrolments in formal school } \\
\text { (previously n=0) } \\
20 \text { informal centres onsite } \\
\text { Attitude changes in brick kiln owners } \\
\text { and parents (not reported) }\end{array}$ & $\begin{array}{l}\text { Very low: } \\
\text { Non experimental data. }\end{array}$ \\
\hline
\end{tabular}


Table 3. Interventions for reducing the impact of hazardous labor for children working in other forms of hazardous labor in Nepal (n=6)

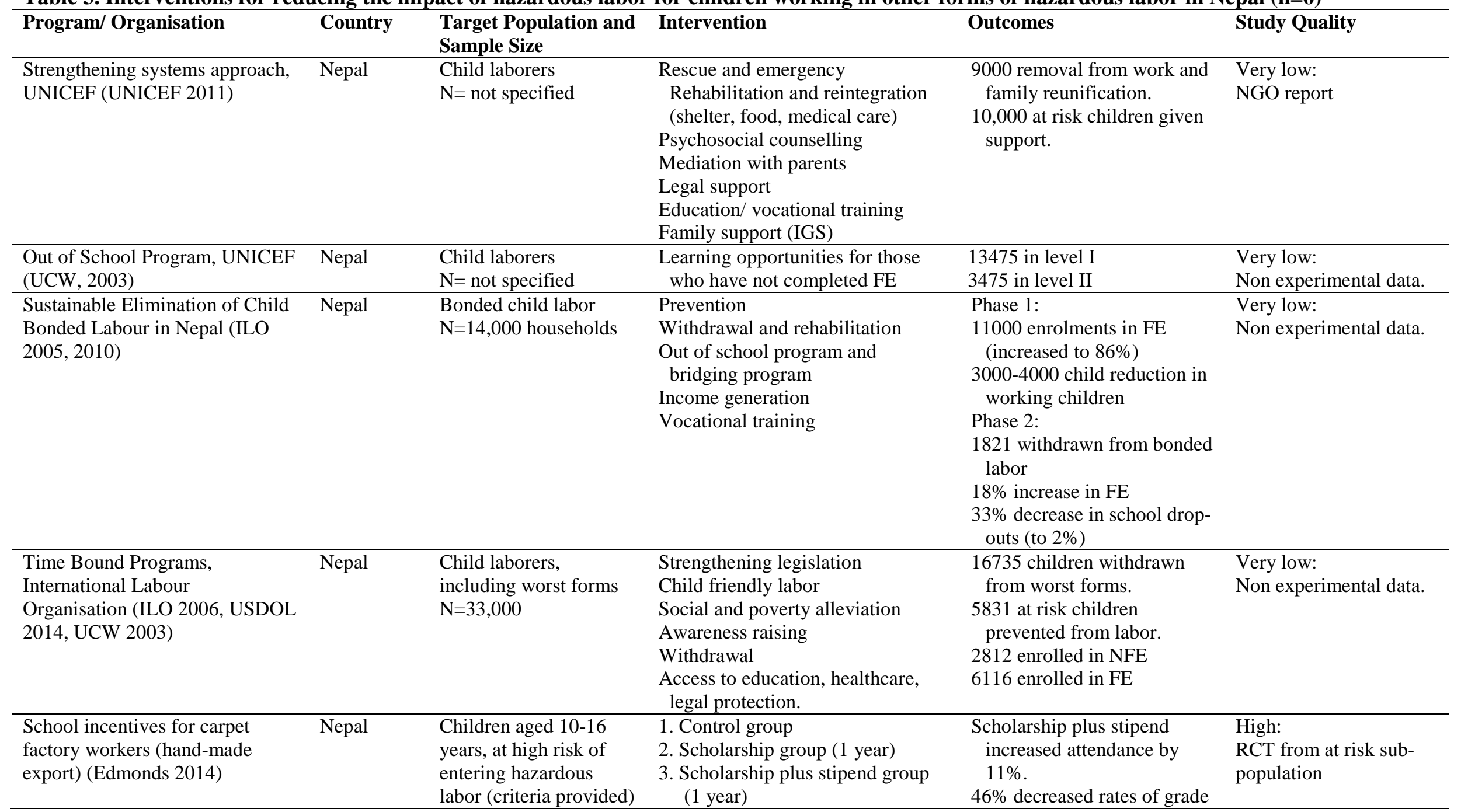


$48 \%$ reduced carpet weaving.

Effects did not persist beyond

Non-Formal Primary Education

Nepal

Disadvantaged

children, including

Condensed primary education (3

$\mathrm{NE}$

laborers

years)

Very low:

Program, Nepal Ministry of

Education 2015)

Key: FE, Formal Education; IGS, Income Generating Support; NFE Non-Formal Education; NE No Evaluation 
Records identified through database searching $(n=182)$
Additional records identified through other sources $(n=144)$

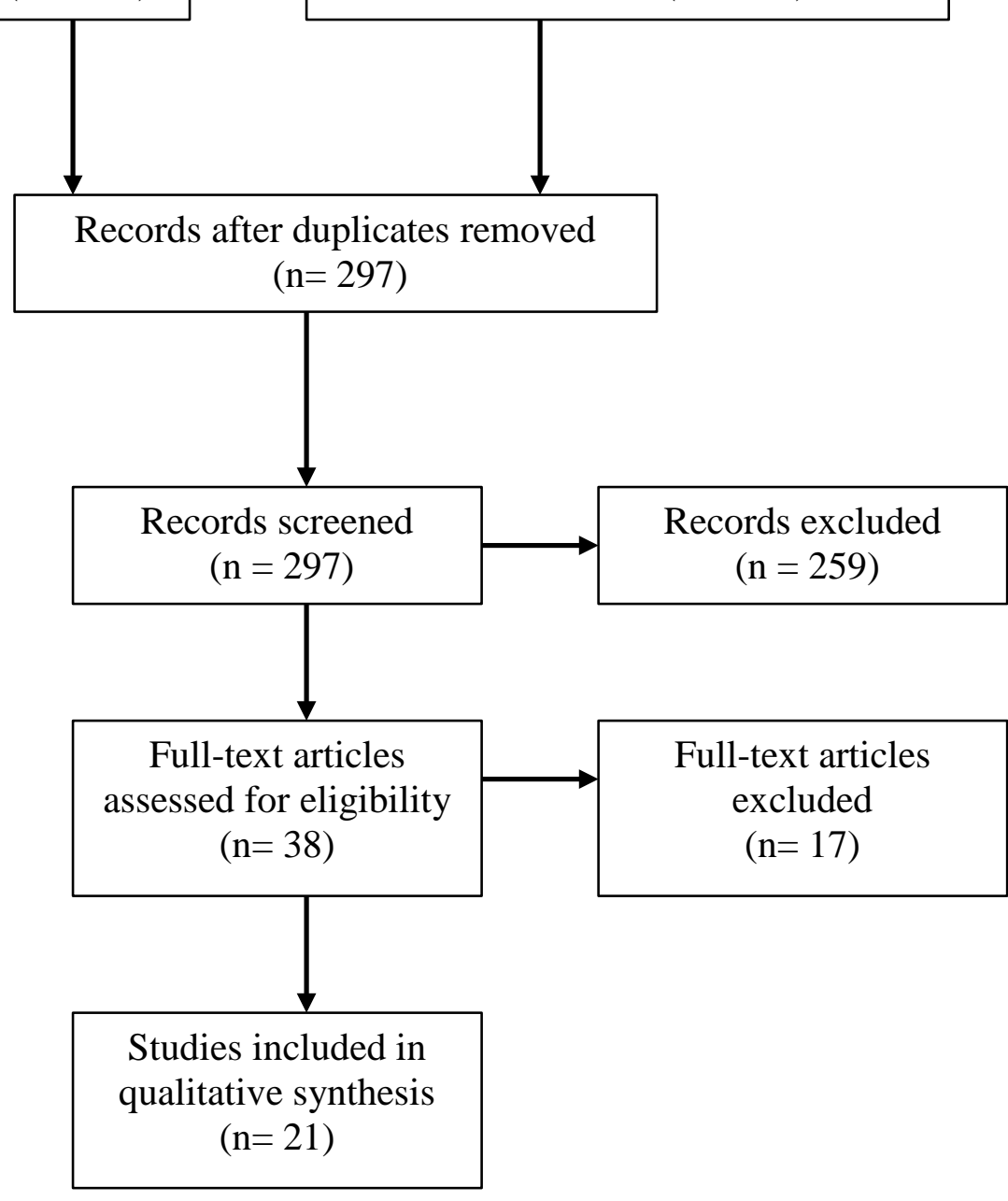

Figure 1. PRISMA Flowchart of Review Strategy 